University of South Carolina

Scholar Commons

Faculty Publications

Criminology and Criminal Justice

1994

\title{
How Reasonable is the Reasonable Man?: Police and Excessive Force
}

Geoffrey P. Alpert

University of South Carolina - Columbia, geoffa@mailbox.sc.edu

William C. Smith

Follow this and additional works at: https://scholarcommons.sc.edu/crim_facpub

Part of the Criminal Procedure Commons, and the Law Enforcement and Corrections Commons

\section{Publication Info}

Published in Journal of Criminal Law and Criminology, Volume 85, Issue 2, 1994, pages 481-501.

Alpert, G. and Smith, W. (1994). How Reasonable is the Reasonable Man?: Police and Excessive Force. Journal of Criminal Law and Criminology, 85(2), 481-501.

Copyright $(1994$ by Northwestern University, School of Law.

This Article is brought to you by the Criminology and Criminal Justice at Scholar Commons. It has been accepted for inclusion in Faculty Publications by an authorized administrator of Scholar Commons. For more information, please contact digres@mailbox.sc.edu. 


\section{HOW REASONABLE IS THE REASONABLE MAN?: POLICE AND EXCESSIVE FORCE}

\section{GEOFFREY P. ALPERT* and WILLIAM C. SMITH**}

The authority of the police to use force represents one of the most misunderstood powers granted to representatives of government. Police officers are authorized to use both psychological and physical force to apprehend criminals and solve crimes. ${ }^{1}$ This Article focuses on issues of physical force. After a brief introduction and a review of current legal issues in the use of force, this Article presents an assessment of current police policy development. After establishing the fundamental foundation for the use of force, the Article discusses "reasonableness" and the unrealistic expectation which is placed on police to understand, interpret, and follow vague "reasonableness" guidelines. Until the expectations and limitations on the use of force are clarified, in behavioral terms, police officers will be required to adhere to the vague standards of the "reasonable person."

\section{INTRODUCTION}

The United States Civil Rights Commission reviewed police use of force in the early 1980s and reported:

Police officers possess awesome powers. They perform their duties under hazardous conditions and with the vigilant public eye upon them. Police officers are permitted only a margin of error in judgment under conditions that impose high degrees of physical and mental stress. Their general responsibility to preserve peace and enforce the law car-

* Professor, College of Criminal Justice and Research; Professor, Institute for Public Affairs University of South Carolina. Appreciation is expressed to Victor Kappeler and Kathryn Urbonya for their helpful comments on earlier drafts of this manuscript.

** Senior Consultant, Criminal Justice Consulting and Training Division, Sedgwick James of the Carolinas.

1 Psychological force or a show of authority can be a police presence, an order (either verbal or visual), or some other form of coercion or deception used to gain a suspect's compliance. Illinois v. Perkins, 496 U.S. 292 (1990); see generally, GeOFFrey P. AlPERT AND Lorie M. Fridell, Police Vehicles and Firearms: Instruments of Deadly Force (1992); Fred E. Inbau et al., Criminal Interrogation and Confessions (1986); Richard A. Leo, From Coercion to Deception: The Changing Nature of Police Interrogation in America, 18 CRIME, L. and Social Change 35 (1992). 
ries with it the power to arrest and to use force-even deadly force. ${ }^{2}$

The Commission Report discussed the need for scrutiny of the police and the need for reform. ${ }^{3}$ Unfortunately, no one attempted to define excessive force or explain situations that went beyond the necessary force needed to achieve the police mission.

This lack of definition has created an unfortunate situation for both the police and the public. One possible consequence of this deficiency is the lack of national and state-wide statistics on police use of force or excessive force. The shortage of comprehensive statistical information on police use of force has been explained by police officials: ${ }^{4}$

[A]gencies did not require reports of their use [of force] from their officers. The categories of force for which such reporting as most likely to be mandated were those with the most potential for death or serious bodily harm, such as shootings. . . . A majority of the agencies within each type reported that they reviewed all use of force reports. The remaining departments either reviewed selected reports or reported that they did not review these reports at all.

One of the best estimates of excessive force incidents was reported in a Gallup poll taken in March, 1991. The critical question asked to a sample of citizens was: "Have you ever been physically mistreated or abused by the police?" Some members of the sample may have interpreted "mistreated or abused" as a perilous attack, and, as a result, responded in the negative, even if they felt that they had been psychologically mistreated or abused, but not violently attacked. Incredibly, $5 \%$ of all respondents and $9 \%$ of non-whites said that they had been mistreated or abused by police. When asked if the respondent knew anyone who had been physically mistreated or abused by the police, $20 \%$ said that they did. ${ }^{5}$ Estimates of excessive force from observational studies range from $1.05 \%$ to $5.1 \%$ of citizen contacts. ${ }^{6}$ Amazingly, several studies revealed that one-third of all use of force incidents could be classified as excessive. ${ }^{7}$ There is no doubt that po-

2 United States Civil Rights Comm'n, Who Is Guarding The Guardians v (1981).

3 Id.

4 See generally Anthony M. Pate \& Lorie A. Fridell, Police Use Of Force: Official Reports, Citizen Complaints, and Legal. Consequences 64 (1993).

5 George Gallup, Jr., The Gallup Poll, March 20, 1991, at 2-3.

6 Robert Worden, The Causes of Police Brutality: Theory and Evidence on Police Use of Force, in And Justice For All: Understanding And Controlling Police Abuse Of Force (W. Geller \& H. Toch eds.) (forthcoming, 1995) (reporting 1.05\%); Robert J. Friedrich, Police Use of Force: Individuals, Situations and Organizations, 452 Annals Am. ACad. Pol. \& Soc. ScI. 82, 87 (1980) (reporting 5.1\%).

7 Worden, supra note 6 , at 17 , (reporting that excessive force was used in one-third of the cases in which force was used); Friedrich, supra note 6, at 90, (reporting that excessive force was reported in $35 \%$ of the incidents in which force was used). PATE \& FRIDELL, supra note 4 , reviewed this literature. 
lice use physical force and that it is frequently perceived as excessive. Understandably, however, the police claim that excessive force is employed less often than observers or citizens report. ${ }^{8}$ The targets of police abuse are almost always lower class males, and the most common factor associated with abuse is disrespect shown to the police by these suspects. ${ }^{9}$

\section{The Legal "STANDARD"}

Prior to 1989, most federal circuits followed the Fourteenth Amendment substantive due process "shocking to the conscience" standard enunciated by the Second Circuit in Johnson v. Glick. ${ }^{10}$ Under Johnson, the subjective mental state of the offending officer was relevant as a factor to help determine if an actionable injury had occurred. ${ }^{11}$ As a result, ambiguity existed in police misconduct cases regarding the standard of evaluation for claims of excessive force. With the United States Supreme Court's 1989 decision in Graham v. Connor, ${ }^{12}$ the significance of that intent gave way to the "objective reasonableness" standard of the Fourth Amendment in cases where "seizures" are deemed to have occurred. ${ }^{13}$

One of the obvious problems created by a reasonableness standard is determining the appropriate level of reasonableness. Research results have indicated that police officers, especially street officers, are able to assess what is good police work and when force is excessive. ${ }^{14}$ This may explain why most accusations of excessive force are denied at the department level. Of course, it may also be that police officers band together, close ranks, and protect their fellow of-

\footnotetext{
8 Worden, supra note 6 , at 18 .

9 Albert J. Reiss, Jr., The Police and the Public 147 (1971).

10 Johnson v. Glick, 481 F.2d 1028, 1033 (2d Cir.), cert. denied, 414 U.S. 1033 (1973).

11 Four factors were cited in Johnson as determinative of whether police use of force was excessive:

1) Need for application of force;

2) Relationship between the need and the amount of force;

3) Extent of injury; and

4) Whether force was applied maliciously and sadistically for the very purpose of causing harm.

Id.

12 Graham v. Connor, 490 U.S. 386 (1989).

13 In non-seizure cases, sharper focus has been brought on the classification of the underlying behavior. For example, the Supreme Court ruled in 1986 that "mere negligence" will not support an action under 42 U.S.C. $\$ 1983$ for substantive due process violations. See Daniels v. Williams, 474 U.S. 327 (1986). The decision may have significant impact on claims filed by non-suspect third parties for injuries allegedly attributable to the police.

14 See generally Hans Toch et al., Agents of Change: A Study in Police Reform (1975).
} 
ficers against accusations of excessive force. ${ }^{15}$ In any case, it is not the police officer who will ultimately determine the reasonableness of another police officer's actions, as police officers will rarely be seated on a jury in a police misconduct case. Reasonableness may have several levels and several audiences. It is, however, the assessment of force by the civilian "reasonable person" that matters. And force may involve hands, batons, or other weapons if used appropriately and according to policy and training. ${ }^{16}$

Police officers may justifiably escalate the use of force against a suspect-beginning with mere presence or verbal and visual commands, and concluding, if necessary, with the use of deadly force-in direct relation to the reason for which they must apprehend that suspect. To determine whether that force was justified, courts must analyze its necessity and reasonableness. ${ }^{17}$ It is precisely these terms that must be defined and understood. A definition of permissible and impermissible (excessive) force must be situationally appropriate, rather than academically or judicially strained. Current legal efforts to define the extent of officer qualified immunity serves as a starting point in the present effort to delineate reasonable standards of officer behavior in situations involving the use of force.

Since its 1987 decision in Anderson $v$. Creighton, ${ }^{18}$ the United States Supreme Court has provided immunity from personal liability to officers whose actions, although resulting in otherwise actionable injury, did not violate "clearly established" law. The essential issue after Anderson, however, has been what the clearly established law was at the time of the officer's actions. At first blush, the Anderson standard seems easy to apply. Judicial guidance could be the ultimate test of the objectivity of police conduct. In practice, however, the rule has been subjectively and inconsistently applied. The lower federal courts are split on the question of whether an officer who uses force which has been determined, after the fact, to be excessive can assert an objective good faith as a defense and avoid personal liability. The Tenth Circuit, in Street $v$. Parham, rejected good faith as a defense and stated that no officer could "reasonably believe that the use of unreasonable force did not violate clearly established law." ${ }^{19}$ Other courts, however,

15 Victor Kappeler et al., Forces of Deviance: Understanding the Darkside of PoLICING Ch. 4 (1994).

16 Geoffrey P. Alpert \& William C. Smith, Developing Police Policy: An Evaluation of the Control Principle, 13 Aм. J. Police 1-20 (1994).

17 See Jerome H. Skolnick \& James J. Fyfe, Above the Law: Police and the Excessive UsE OF FORCE 38-42 (1993); Richard E. Sykes \& Edward E. Brent, The Regulation of Interaction by Police, 18 Criminology 182, 186-88 (1980).

18 Anderson v. Creighton, 483 U.S. 635 (1987).

19 Street v. Parham, 929 F.2d 537, 540 (10th Cir. 1991). 
have held that even if the force used was excessive, good faith immunity may still be available. ${ }^{20}$ These divergent views raise a troublesome tautological question: If the legal issue is whether the officer's behavior was reasonable, so that qualified immunity may apply, can officers ever conclude that their behavior was reasonable if a court later concludes that it was not? Similar issues include whether the result of prior trials-which may have been largely fault driven-provide any guidance for similar officer behavior in other contexts (i.e., whether behavior deemed reasonable in one context would be deemed reasonable in similar settings, and whether behavior for which there has been no clearly established judicial precedent can be so "obviously" reasonable or unreasonable as to render the question of good faith moot in a particular context). ${ }^{21}$

All that can be gleaned from available guidance is that police behavior must be reasonable in the given situation. Unfortunately, the focus of the present analysis is after the fact of occurrence; a judicial model. From the operational and risk management perspective, however, control of police excessive force requires front-end identification of acceptable standards of behavior. The terms "force necessary" and "reasonable" need to be defined.

The reasonableness of officers' actions may be subsequently assessed by their co-workers, their superiors, a civilian review panel, or a jury. Police officers and supervisors rely upon their backgrounds, experiences, and biases to determine the reasonableness of force used by fellow officers. Similarly, members of civilian review panels may seek input from other community members or may respond to their perception of public opinion. However, if a claim of excessive force goes beyond an internal police investigation or civilian review, a civilian jury may likely be assisted by expert witnesses ${ }^{22}$ who provide testimony concerning the appropriateness of police action according to currently accepted police practices and training.

Expert witnesses frequently help jurors to evaluate the reasonableness of a police officer's actions. The appeal of expert testimony, even on a post hoc basis, is that it involves an assessment of the situational conduct of the police by a person who can analyze the police actions in their appropriate context. ${ }^{23}$ The jury has the benefit of

20 See Finnegan v. Fountain, 915 F.2d 817 (2d Cir. 1990); Lester v. City of Rosedale, 757 F. Supp. 741 (N.D. Miss. 1991).

21 See, e.g., Yates v. City of Cleveland, 941 F.2d 444 (6th Cir. 1991) (denying good faith immunity to a police officer who entered a residence at night without a warrant and without identifying himself and who shot the resident who responded to the entry).

22 The difficulties inherent in evaluation of expert witness testimony and assessment of expert witness credentials are beyond the scope of this article.

23 See generally Expert Witnesses (Patrick R. Anderson \& L. Thomas Winfree, Jr. eds., 
hearing both sides of the story and their interpretations by "experts." How the jurors interpret the information raises a variety of questions based on societal and personal expectations.

On one hand, citizens expect the police to be aggressive in the enforcement of the criminal law against serious offenders. On the other hand, citizens expect the police to show restraint when they are personally involved. In effect, a dual standard of conduct is expected of the police in citizen encounters. This dual standard is premised on a hybrid concept which can best be described as "subjective objectivity." Subjective objectivity is the essence of the "reasonable person." And it is the assessors' duty to determine if the police actions were reasonable or unreasonable based upon subjective objectivity. Any attempt to distinguish legally between permissible force and excessive force is clouded by this hybrid concept. While these two guides (subjectivity and objectivity) are conceptually linked, they require different interpretations of performance. Efforts to quantify what is "reasonable" vis a vis that which is "excessive," have invariably resulted in the confusing tautology. ${ }^{24}$ What is reasonable has become what is necessary.

\section{The Problem with the Current Standard}

It is the "objectiveness" of the standard which creates the present conundrum. Under Johnson, judicial evaluation was an integral part of the inquiry into the "reasonableness" of the police action. Since Graham, however, the objectivity assessment for police use of force has become a "guided tour" with a different guide for each tour (i.e., the expert witness). Police administrators must develop policies and procedures for line officers based on the anticipated direction of the "reasonable person." Identifying what is "reasonable" in a given encounter is a difficult challenge which must move beyond the limits of our present method of analysis.

The current standard has forced police departments to create policies on the use of force that are unworkable. Police policies have attempted to provide basic behavioral guidance to officers as well as limiting their (and the department's) exposure to liability. Perhaps the most influential policy on the use of force is the Model Policy developed by the International Association of Chiefs of Police (IACP). ${ }^{25}$ This policy suggests:

\footnotetext{
1987).
}

24 See Victor E. Kappeler \& Rolando V. delCarmen, Police Civil Liability for Failure to Arrest Intoxicated Drivers, 18 J. CRIM. Just. 117, 127-28 (1990).

25 National Law Enforcement Policy Ctr., Int'l Ass'n of Chiefs of Police, A ComPiliation OF MOdel Policies $§ 1$ (1989-1991). 
[P] olice officers shall use only that force that is reasonably necessary to effectively bring an incident under control, while protecting the lives of the officer or another. . . . Police officers are authorized to use department-approved nondeadly force techniques and issued equipment for resolution of incidents, as follows:

a. To protect themselves or another from physical harm; or

b. to restrain or subdue a resistant individual; or to bring an unlawful situation safely and effectively under control. ${ }^{26}$

The IACP provides no guidance on what the phrase "reasonably necessary" means or how to interpret it, but it discusses the "reasonable man":

The model policy adopts the "reasonable man" standard in this and similar contexts to establish whether an officer's actions under given circumstances were justifiable. This test asks: What would reasonable police officers do under the same or similar circumstances? ${ }^{27}$

The IACP does not distinguish between the "reasonable man" and the "reasonable police officer." Similarly, there is no discussion concerning technology and the fact that what may have been reasonable force a few years ago may not be reasonable today. The welltrained police officer may view the dynamics in a police-citizen encounter differently than a non-officer or even a poorly trained officer. Similarly, the well-trained officer may come to a different conclusion than others about what is necessary and reasonable to resolve the encounter. Therefore, it is essential to inform police officers about this potential difference in opinion and the consequences of using force which an officer may approve but a civilian would not understand and therefore condemn. It is necessary to keep officers up-to-date on technological advancements which can reduce the need for the use of force and, particularly, deadly force. For example, if ten years ago unruly suspects fought with police or began kicking out the windows of a patrol car, it may have been appropriate to hog-tie them to insure both the officer's and the suspect's safety. Today, however, police have more humane restraint devices.

\section{Beyond the Law and Policies}

While both the laws and police polices limit officers' ability to use unrestricted force, neither has been able to define the limits of reasonable force. Similarly, neither has been able to guide the police executive or the social scientist on how to measure the use of excessive force. However, both acknowledge that officers need proper authority and training if they are to use force properly to apprehend sus- 
pects. An analysis of laws and policies does little to clear away the ambiguity and the same questions remain: (1) What is excessive force, and (2) How is it distinguished from reasonable force?

Few courts have attempted to distinguish between reasonable and excessive force, and each has suffered from fatal flaws. It is unnecessary to trace and comment on the numerous attempts to delineate the analyses of the various degrees of force used by the police. ${ }^{28}$ It is sufficient to recognize some of the most powerful or popular statements that have been published concerning police violence, which distinguish between "instrumental aggression" and "affective aggression."

The psychological concepts of "instrumental aggression" and "affective aggression" respectively refer to actions intended to accomplish legitimate goals and actions intended to harm or injure persons. ${ }^{29}$ Egon Bittner applied these concepts to police actions and distinguished police use of unnecessary violence from the exercise of "provoked force." 30 Bittner's premise was that violence is unnecessary and unreasonable, while provoked force is required to fulfill the police mission.

These ideas were revisited and altered by Skolnick and Fyfe. ${ }^{31}$ They took Bittner's concepts, transformed them into two types of unnecessary violence, and labelled them "brutality" and "unnecessary force." They describe brutality as "a conscious and venal act committed by officers who usually take great pains to conceal their misconduct." 32 They describe unnecessary force as "ineptitude or insensitivity, such as, when well-meaning officers unwisely charge into situations from which they can extricate themselves only by using force. . . . Unnecessary force may be a good-faith police mistake." ${ }^{33}$ Good faith plays no part in brutality. ${ }^{34}$ These distinctions hinge on the faith or intent of the actors. Perhaps Skolnick and Fyfe formed these ideas under the influence of the Johnson decision.

Almost a decade ago, Fyfe used the psychological concepts and distinguished between brutality and unnecessary violence by stating: ${ }^{35}$

28 For example, the interpretations of the Fourth Amendment's objective reasonableness standard in police-citizen encounters are varied. Cf. Campbell v. White, 916 F.2d 421 (7th Cir. 1990); Lester v. City of Chicago, 830 F.2d 706 (7th Cir. 1987); Mederios v. Town of South Kingston, 821 F. Supp. 823 (D. R.I. 1993).

29 Robert A. Baron, Human Aggression 23-47 (1977); Curt Bartol, Criminal BehavIOR: A PSYchological ApProach 54-76 (1991).

30 Egon Bittner, The Functions of Police in Modern Society 20 (1970).

31 See generally SKOLNICK \& FYFE, supra note 17.

32 Id. at 19.

33 Id. at 20. "Good faith," however, has no place in the analysis of reasonableness of incustody police seizures after Graham v. Connor, 490 U.S. 386 (1989).

34 SKOLNICK \& FYFE, supra note 17, at 20.

35 See generally James Fyfe, The Split-Second Syndrome and Other Determinants of Police Vio- 
Discussions of police violence are often blurred by the failure to distinguish between violence that is clearly extralegal and abusive and violence that is simply the necessary result of police incompetence. This distinction is important because the causes of these two types of violence, and the motivations of the officers involved, vary greatly. Extralegal violence involves the willful and wrongful use of force by officers who knowingly exceed the bounds of their office. Unnecessary violence occurs when well-meaning officers prove incapable of dealing with the situations they encounter without needless or too hasty resort to force. ${ }^{36}$

Fyfe's point was that police officers are put in situations, or put themselves in situations, that require the use of force to apprehend suspects. For example, after officers have argued with a suspect or have concluded a foot or vehicle pursuit and have made the decision to take the suspect into custody, they must restrain the suspect. Fortunately, the suspect usually cooperates. At times, however, suspects need to be physically restrained. Police may use force, albeit unnecessary force, as self defense, because they have been placed in or have created a situation from which they cannot retreat. ${ }^{37}$ Brutality rears its head, however, when a police officer chooses or intends to use force beyond what is reasonably necessary to apprehend a suspect.

Carl Klockars provides another example. ${ }^{38}$ Klockars defined excessive force as "the use of any more force than a highly skilled police officer would find necessary to use in that particular situation." 39 This definition merely adds "highly skilled" to a reasonable (police) man standard, and is as deficient as all other generic reasonable person standards. First, as noted, Klockars' definition is contingent upon analysis of a "highly skilled" officer's action. Without nationally accepted training standards, his definition invites a plethora of questions involving the bases by which an officer is to be judged. Second, recognizing the term "necessary" as a restraint on police contextual behavior creates the tautology that what is reasonable is necessary, and "reasonableness" becomes not a standard for police behavior as much as a conclusion.

In sum, the following three concerns must be addressed: (1) how the officer determines if a threat exists; (2) how the officer determines the seriousness of the threat; (3) how the officer controls or removes the threat. While threat assessment is not predisposed to sci-

lence, in Critical Issues in Policing: Contemporary Readings 493 (Roger G. Dunham \& Geoffrey P. Alpert eds., 1993).

36 Id.

37 Note, Police Liability for Creating the Need to Use Deadly Force in Self Defense, $86 \mathrm{MICH}$. L. Rev. 1982 (1988).

38 Carl Klockars, $A$ Theory of Excessive Force and Its Control, in AND Justice For AlL, supra note 6 .

39 Id. at 11. 
entific analysis, research on police and sequential decision theory can provide factors and situations that can help an officer evaluate a potential threat and can assist in the analysis of police use of force. ${ }^{40}$ Two critical types of threats must be analyzed: escape and physical threat.

\section{A. ESCAPE}

If a suspect is attempting to flee a police officer, what force can an officer use to apprehend the suspect? Two examples may help answer the question. First, if a suspect is running away from the officer and has not posed an imminent threat to the officer or a citizen, then reasonable force may not include the shooting of the suspect. ${ }^{41}$ Second, if a suspect is attempting to escape from an officer who is fighting with the suspect, reasonable force may include only enough effort to constrain the suspect without using what would be considered deadly force such as a choke hold, strike to the head with a weapon, knee on the neck, etc.

The critical question remains: should the police allow a suspect to escape or should they prevent escape by using a continuum of force up to and including what might result in death or great bodily harm? In reality, criminal offenders may attempt to escape from custody if no physical force or threat of real force were available. Police must be permitted to use some degree of force to take suspects into custody and, as long as suspects continue to fight and resist, the police will be authorized to use force to apprehend them. Yet, in attempting to apprehend a suspect, the police must consider the seriousness of the initial offense. Unfortunately, a police officer cannot always recognize when a suspect is merely trying to escape or is willing to harm someone. Officers must be informed on the methods and limits of force which are permissible in the apprehension of a suspected criminal. As long as police use force, complaints of excessive force will be reported, regardless of the officer's or suspect's intent. These claims must be investigated and evaluated in their proper context.

40 Albert J. Reiss, Jr., Controlling Police Use of Deadly Force, 452 Annals Am. Acad. Pol. \& Soc. ScI. 122, 127-33 (1980).

41 Under a literal reading of Garner v. Tennessee, 471 U.S. 1 (1985), a person who has committed a crime involving the actual or threatened infliction of great bodily injury or death may ipso facto pose a "significant threat" to the public. However, a more reasonable interpretation of Garner may require that the risk presented by the offender must be linked directly to the assessed danger posed. For example, an estranged husband who has just murdered his wife may not, under some circumstances, be a danger to the community. 


\section{B. PHYSICAL THREAT}

The second type of threat requiring analysis is a threat of violence, great bodily harm, or death. If a suspect threatens officers or citizens, then those officers must act to protect themselves or the public. In this scenario, the perception of the officer is critical. For example, if an officer perceives a suspect pointing a gun and it turns out to be a toy gun, it is the perception that is important rather than the intent of the suspect or the fact that a toy gun does not represent a real threat. If there is a realistically perceived threat that a suspect is placing a life in imminent danger, then officers can take the life of a suspect to protect their own lives or that of an innocent bystander. However, this scenario becomes complicated if either the suspect is in a location or a position in which the use of deadly force or force sufficient to constrain the suspect by an officer might place other lives in danger, or if the threat is not genuine. An officer will have to rely on available information, training, and available alternatives before employing force significantly dangerous to the public. Next, it is necessary to examine the total situation surrounding the use of force, from the approach to the final frame.

\section{Preliminary Frames versus the final Frame}

The concepts defining reasonable force should assist in the creation of a standard to measure how a reasonable police officer should act and be judged, rather than setting the stage for a rear-view mirror analysis of what has transpired. It is likely that many reasonable and even highly-skilled officers would respond similarly in a given factual scenario that a jury has determined to be unreasonable conduct ${ }^{42}$ At a minimum, all officers must follow common guidelines. It is important to look at events which transpired before the final act or acts of force to determine reasonableness in either an escape or threat situation. Albert Reiss, writing in the late 1970s, was the first to recognize the need to analyze police actions in stages. ${ }^{43}$ Reiss suggested that officers must be held accountable for their actions and not merely the final frame of a confrontation. In many police-citizen encounters, officers can escalate the probability of a serious threat by their demeanor or actions. Similarly, officers can de-escalate a potentially violent situation by their demeanor or action. ${ }^{44}$ In those situations as

42 As noted, the police may assess the extent of force differently than observers or citizens.

43 Reiss, supra note 40 , at $127-30$.

44 Arnold Binder \& Pete Scharf, The Violent Police-Citizen Encounter, 452 Annals Am. ACAD. POL. \& Soc. SCI. 111, 116-18 (1980); Reiss, supra note 40, at 127-33. 
well, the preliminary frames are critical in determining whether officers may use force against a suspect. As Reiss noted in 1980: "The sequences of behavior in encounters that lead up to the deadly force sequence are ones in which external information can be taken into account and in which [an] alternative course of action can be considered." 45 While it makes sense to analyze the circumstances leading up to a police action, the law has limited the scope of that analysis in some federal cases. ${ }^{46}$ The distinction made by some federal courts is that an officer's "liability be determined exclusively upon an examination and weighing of the information [the officers] possessed immediately prior to and at the very moment [they] fired the fatal shot[s]." 47 Certainly, there are stages or sequences of preparation and decisions for police to plan or design.

For example, the conduct of an officer at a traffic or investigative stop can increase the likelihood that a suspect will say something to the officer that will escalate the potential for a violent action or reaction. Similarly, officers may respond to a call inappropriately and place themselves in a position where force is necessary as self-defense. In such situations, it is critical to analyze the interaction between the suspect and the officers, the initial actions of the officers as they arrive on a scene, or what they are told by their dispatcher.

In many situations, the police officer has time to make decisions. Normally, these decisions permit a three-frame analysis of police behavior. The first frame includes activities prior to any contact with the suspect. These activities include the approach to the scene, the accumulation of tactical information, and taking cover. These activities are concerns for officer and departmental negligence, but are irrelevant in the determination of a constitutional violation in some jurisdictions. $^{48}$ The second frame consists of actions and behavior conducted "immediately prior" to the use of force and begins when the police officer makes contact with the suspect, either physical, verbal, or visual. An officer's actions and reactions during the interaction with the suspect creates an environment which can escalate or de-escalate the potential violence of an encounter and can be included in the analysis of reasonableness. The final frame is the decision and use of force which causes the injury. This frame can include any force, such as the discharge of a firearm or the use of a chokehold, baton, fist, or other weapon.

45 Reiss, supra note 40, at 130.

46 See, e.g., Greenidge v. Ruffin, 927 F.2d 789 (4th Cir. 1991).

47 Id. at 792 (quoting Ford v. Childers, 855 F.2d 1271, 1275 (7th Cir. 1988) (quoting Sherrod v. Berry, 856 F.2d 802, 805 (7th Cir. 1988))).

$48 I d$. 
While some federal courts limit their liability assessment to the second and third frames, it is important for police administrators and trainers to include all frames in their analysis and training. Perhaps the most critical frame is the farthest from the injury. The more information known about a situation, the approach made by the police, and the placing of officers in a safe situation to avoid a threat and prevent a stress situation will probably decrease the likelihood of violence and the need to use force more than any other strategy. A use of force application may be justified but avoidable.

In other police-citizen encounters, officers may have no control over the preliminary frames as they are forced into the final frame. That is, the officers must make a split-second decision to save themselves or someone else from serious bodily harm. In this predicament, the officers' actions and the force employed will be easier to analyze than in an incident in which the preliminary frames are also in question.

\section{Antecedents of Police Use of Force}

To gain a complete understanding of the force applied, it is important to obtain information from all persons involved and all persons witnessing the event. Obviously, police investigators must focus their inquiry on these factors, ${ }^{49}$ and officers involved must report their understanding of what occurred. The best method of memorializing the officers' opinions is to have a comprehensive "Use of Force" or "Control of Persons Reporting" form which includes information concerning the situation, environment, participants, and injuries as well as the suspect's perceived mental state, level of resistance, level of force, and type of force. As further documentation, a supervisor should complete a report which reviews the situation and the environment and analyzes the reasonableness of the force used compared to the suspected offense and level of resistance..$^{50}$

Findings from prior research have demonstrated that at least five layers of analysis are necessary to evaluate police use of force: ${ }^{51}$ (1) The Organizational Atmosphere of the Agency; (2) The Situation; (3) The Environment; (4) The Participants and Their Relationships; and

49 James N. Gilbert, Criminal Investigation 242-71 (1993); Richard A. Myren \& Carol H. Garcia, Investigations for Determination of Fact: A Primer on Proof 32-33 (1989); Roy F. Roberg \& Jack L. Kuykendall, Police and Society 253-59 (1993).

50 For example, the Metro-Dade Police Department in Miami, Florida has developed an excellent reporting system, including a Supervisor's Report of Use of Force to Control. See Metro-Dade Police Dep't, Departmental Manual-1994, Part 1, at 2-34 to 2-34.5 (1994).

51 See generally ANd Justice For All, supra note 6; William A. Geller \& Michael S. Scott, DeAdly Force: What We Know (1992); PATE \& Fridell, supra note 4; Friedrich, supra note 6; Reiss, supra note 40. 
(5) Any Sustained Injury.

\section{A. ORGANIZATIONAL ATMOSPHERE}

The culture or normative expectations of officers in the police agency may influence the level of force that they deem reasonable. ${ }^{52}$ First, the training that academies provide will define and shape the alternatives available to the officers. As Geller and Scott report, "The empirical literature has recommended training in four basic areas: (1) policy interpretation; (2) human relations and 'cultural awareness' skills; (3) conflict management techniques (training in physical, verbal, and judgmental 'violent-reduction' tactics); and (4) tactics for the proficient use of weapons when shooting is required." 53 Second, police culture plays a significant role in the consent or sanction of force. It has been noted that "the police subculture reinforces and provides encouragement for certain types of deviance and corruption, and discouragement for other types. It appears that in many departments, a distinction is made between 'clean' and 'dirty' money, as well as between approved and disapproved corruption and deviance." 54 From their work in Los Angeles, Skolnick and Fyfe conclude that officers will interpret a department's history and acceptance of the use of force. ${ }^{55}$

It is also important to understand how the administrators evaluate officers' actions and the disciplinary system that exists in an agency. For example, if administrators do not question officers' actions unless a citizen files a complaint, and when a citizen files a complaint, the investigation is narrow or limited, then officers become accustomed to a practice that permits unreasonable police activities.

\section{B. THE SITUATION}

The information from situational variables which needs to be collected and analyzed includes the character of the offense for which the suspect is wanted, the behavior of the citizen(s), and the characteristics of the citizens. For example, a violent felony, which may justify the use of severe or even deadly force, must be analyzed with different tolerance levels than a minor property offense. The seriousness of the offense will determine the amount of force which can be justified. ${ }^{56}$

\footnotetext{
52 Kappeler et AL., supra note 15, at 91-118; SKOLNICK \& FyFe, supra note 17, at 89-112.

53 Geller \& SCOTT, supra note 51, at 297.

54 Geoffrey P. Alpert \& Roger G. Dunham, Policing Urban America 107 (1992).

55 SKOLNick \& FYFe, supra note 17 , at 12-20.

56 See Garner v Tennessee, 471 U.S. 1 (1985).
} 
The suspect's actions toward the officer or a citizen must be appraised to determine if a threat existed. This behavior will have to be evaluated based upon the information known to the officer. A suspect quickly approaching a police officer with a six-inch knife, which creates a serious and immediate threat, may require that officers use severe or even deadly force, while a suspect who appears very intoxicated carrying a package in one hand and a baseball bat in the other may not pose a serious threat to a trained officer. The officer may be able to defuse the threat by retreating and waiting for back-up or by using a defensive intermediate weapon.

While the characteristics of the suspect, such as race and gender, may influence an officer's reaction or response, they are unlikely to be causal variables and independently do not justify a greater or lesser degree of force. ${ }^{57}$ The age and physical size of the suspect, however, may restrict or encourage the type and amount of force that is justified, depending on whether the suspect has the ability and capacity to use force. ${ }^{58}$

\section{ENVIRONMENT}

It is important to assess both the physical and social environment in which police use force. ${ }^{59}$ Research indicates that the rate of violence in a particular geographic area influences police officers' perception of the environment as dangerous. ${ }^{60}$ In turn, this perception could affect their response to suspects. Additionally, research has demonstrated that the four most frequent events in which violence can potentially break out include: routine traffic stops, stops of suspicious vehicles, and responses to reported crimes and disputes. ${ }^{61}$ Obviously, the area and the precipitating events are important to understanding the environment in which police force exists. An equally important situational factor is the visibility of any police action or reaction to a suspect's behavior. If officers believe they are alone and cannot be seen by fellow officers or the public, they may treat a suspect differently than if they are under the eye of a crowd or a video camera. ${ }^{62}$

57 AlPERT \& Fridell, supra note 1, at 51; Geller \& SCOTt, supra note 51, at 211.

58 PATE \& Fridell, supra note 4, at 19-32.

59 James J. Fyfe, Geographic Correlates of Police Shootings: A Microanalysis, 17 J. REs. CRIME \& DeLINQ. 101, 101-13 (1980).

60 Alpert \& Fridell, supra note 1 , at 45.

61 Metro-Dade Police Dep't, Reports on Use of Force, Officer Injuries, and Citizen Complaints, 1988-1990, at 22 (1991), cited in SKOlNick \& FyFe, supra note 17, at 184.

62 Friedrich, supra note 6, at 91; Geoffrey P. Alpert et al., Implications of the Rodney King Beating, 28 Crim. L. Bull. 469, 469 (1992). 


\section{THE RELATIONSHIP AMONG PARTICIPANTS}

One of the critical issues in any police-citizen interaction, including the use of force, is the officer's and suspect's attitudes toward each other. As noted, an officer can easily reduce the potential for violence in an interaction with a citizen. Similarly, the attitude of a suspect can affect the probability of the police having to use force. ${ }^{63}$ While it may be difficult to discover who said what to whom or how one party acted or behaved toward the other, ${ }^{64}$ these events may provide important linkages to understanding the use of force by police. Additionally, suspects' perceived mental states, and level of resistance, and the nature and type of force used against them must be documented and assessed. ${ }^{65}$

Another important consideration is the ethnic relationship between the officer and the suspect. In any situation in which an officer from one ethnic background uses force on a suspect from another ethnic background, allegations of racism may surface. The ethnic relationship between actors may have nothing to do with the level of force used by the police. However, both ethnic and class differences may influence how each person perceives and subsequently acts toward the other. ${ }^{66}$ In any situation in which the police use force, the outcome of the interaction or the injury to the suspect will determine whether that suspect files a complaint and whether or not there are damages.

\section{E. INJURY}

The nature and extent of an injury sustained by a suspect will frequently bear a strong correlation to a claim of excessive force. On the one hand, many serious injuries may result from legitimate use of force by the police but nonetheless end up being the subject of a complaint. On the other hand, suspects are unlikely to file excessive force claims against the police for slight injuries which are claimed to be a result of unnecessary force. Physical injuries must be evaluated to determine how they occurred and the type and extent of force which caused them. For example, police use of force reports are replete with terms such as "force necessary," which the police use to justify an injury. However, such assertions can be evidence of departmental

63 Samuel Walker, The Police in America 331-33 (2d ed. 1992); Reiss, supra note 9, at 11-26.

64 Roberg \& KuYkendall, supra note 49, at 253-59; KAPPELER ET AL., supra note 15, at 239-70.

65 Metro-Dade Police Dep't, supra note 61, at 2-34 to 2-34.5.

66 Geoffrey P. Alpert \& Roger G. Dunham, Policing Multi-Ethnic Neighborhoods $119-27$ (1988). 
mechanisms used to satisfy after-the-fact oversight. A critical examination of police-inflicted injuries requires integration of the level of force permitted by law and policy. In the event of a civil law suit, the additional factor of medical evidence will be important.

\section{A Recommendation for Applying the Standard}

Once it is necessary for a police officer to use force, its reasonableness must be judged by an assessment of various factors. Specifically, the magnitude of force must be in relation to its necessity. Translated into applied language, this means that the police can use force, including what is necessary, to subdue or restrain a suspect or remove the threat, but must reduce the level of force when a suspect is placed under control or the threat is removed. This simplistic application needs further explanation and analysis. When suspects run away from the police and the police officer cannot catch them, then the suspects may have momentarily won their freedom. If officers catch a suspect who fights with them, they are justified in using force to protect themselves. Similarly, force commensurate with the crime for which a suspect is wanted is justified to apprehend the suspect. However, once a suspect either ceases resistance or has been overpowered, or the threat has been removed, additional use of force becomes excessive. The police must use only simple force or physical direction on suspects after they have been overpowered or controlled. Similarly, the police should communicate to a struggling suspect what is required for the police to decrease the level of force which they are employing. Degrees of force beyond that necessary to maintain police control should be viewed as excessive.

Given a definition of unnecessary or excessive force, the next task is to identify a measure or continuum which police can employ prospectively to gauge their actions, and juries can employ after-the-fact to evaluate intelligently and objectively the classification of force used. An important way to instruct police officers on the reasonable use of force is to explain that their level of control is understood and justified by the suspect's offense and resistance. Of course, these actions are influenced by officer training. Graph 1 illustrates this concept. Graph 1 describes the correlations between the suspect's offense and level of resistance, the officer's level of force to control and apprehend the suspect, and the officer's training. Suspects' behavior, including their resistance and offense, as well as the officer's training, can help define the officer's level of control.

The specific relationships among the factors are displayed in Graph 2. 


\section{Graph 1}

Factors Influencing the Use of Reasonable Force

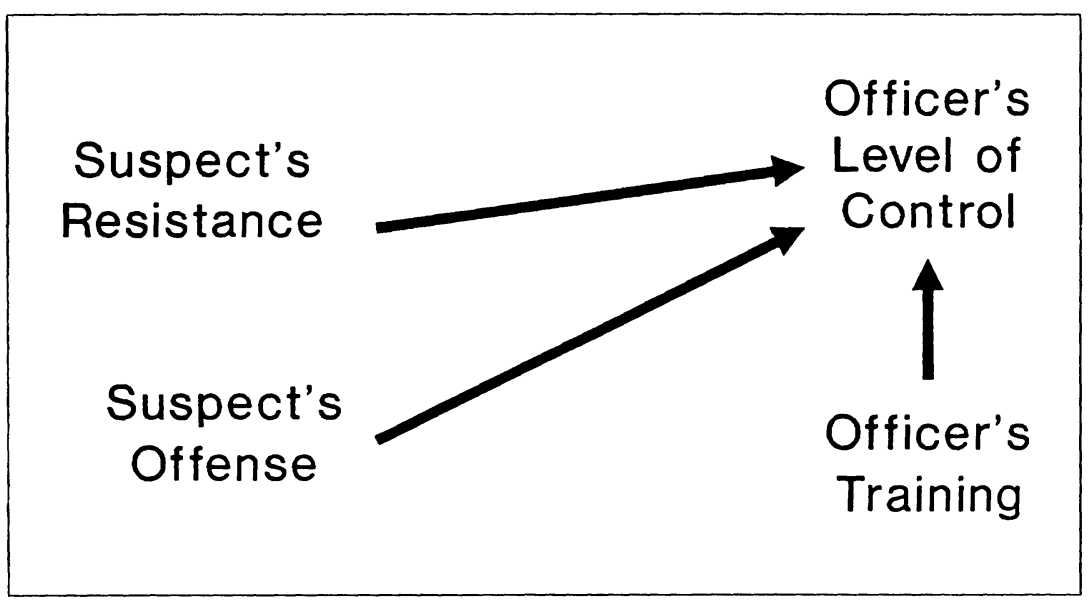

Suspects' resistance increases from verbal non-compliance to lifethreatening behavior. Similarly, their offense can vary from minor to life-threatening. The officer can use control techniques which include verbal and visual commands up to and including life-threatening action or deadly force. The forty-five degree line in Graph 2 represents reasonable behavior in most situations. For example, if suspects do not comply with an officer's request, officers may increase their level of verbal control. If suspects increase their defensive resistance then officers are justified in using physical direction to control the suspect. Similarly, if a suspect becomes aggressive and threatening to the officer or a bystander, the officer may use non-lethal force. The end of the continuum demonstrates that the police may take a suspect's life to save another life. However, one must consider the threat of the suspect to the public if allowed to escape. ${ }^{67}$

The analysis of this use of force matrix requires police to honestly report their actions and the actions of their suspects. While that may be an unrealistic expectation, some assurance that latitude will be given to the situational estimation of the officer on the scene may change the tide of police opinion. Honest reporting is the best way to determine if force applied by the police has been excessive.

Only those officers and citizens involved will actually be affected by or observe the force applied. Each will draw conclusions as to whether it was reasonable or excessive. Even when involved on opposing sides in a use of force situation, citizens and officers typically com-

67 Garner v. Tennessee, 471 U.S. 1, 11 (1985). 
Graph 2

ReAsonable Force

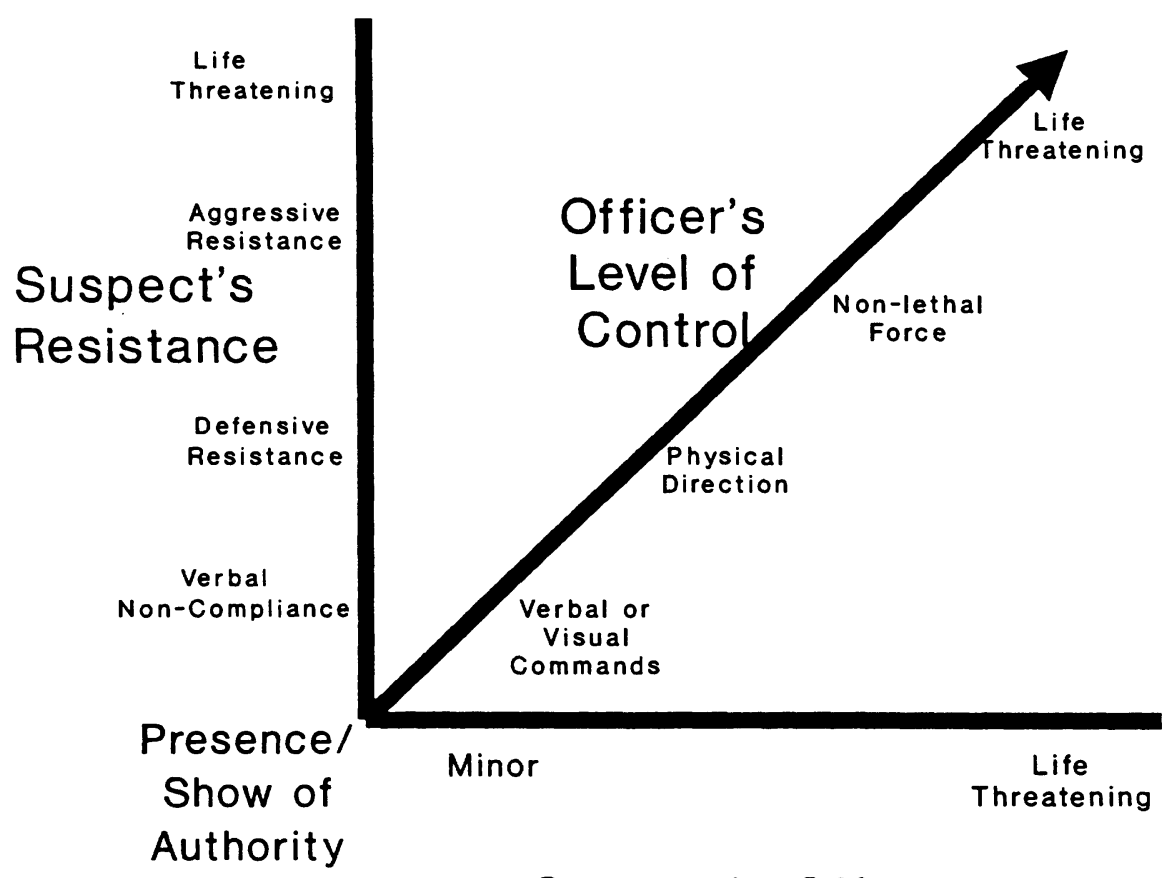

Suspect's Offense

prehend that many acts of force are appropriate to fulfill the police mission. This is where Skolnick and Fyfe's categories of brutality and unnecessary force become critical. Force that is intentional can be conceptually distinguished from that which is unintentional and unnecessary. ${ }^{68}$ However, there may be situations where one or both parties are "caught up" in the interaction or too close to properly analyze if the amount of force used was necessary. To complicate matters, one or more of these actors may have perceived a threat that was not real or that was not as extreme as initially anticipated. Certainly, police officers respond to what they perceive, regardless of the real or actual consequences. The evaluation of a threat is demonstrated in Graph 3. Graph 3 indicates the degree of training that can help an officer determine whether a threat is real or not. The earlier example of a suspect holding a six-pack of beer and a baseball bat and weaving toward the officer illustrates this point. The threat may appear to be serious, requiring an immediate and aggressive response. However, in reality, the threat may be minimal, requiring the officer to merely retreat, call

68 SKolnick \& FYFe, supra note 17, at 37-42. 


\section{Graph 3}

Evaluation of THREAT

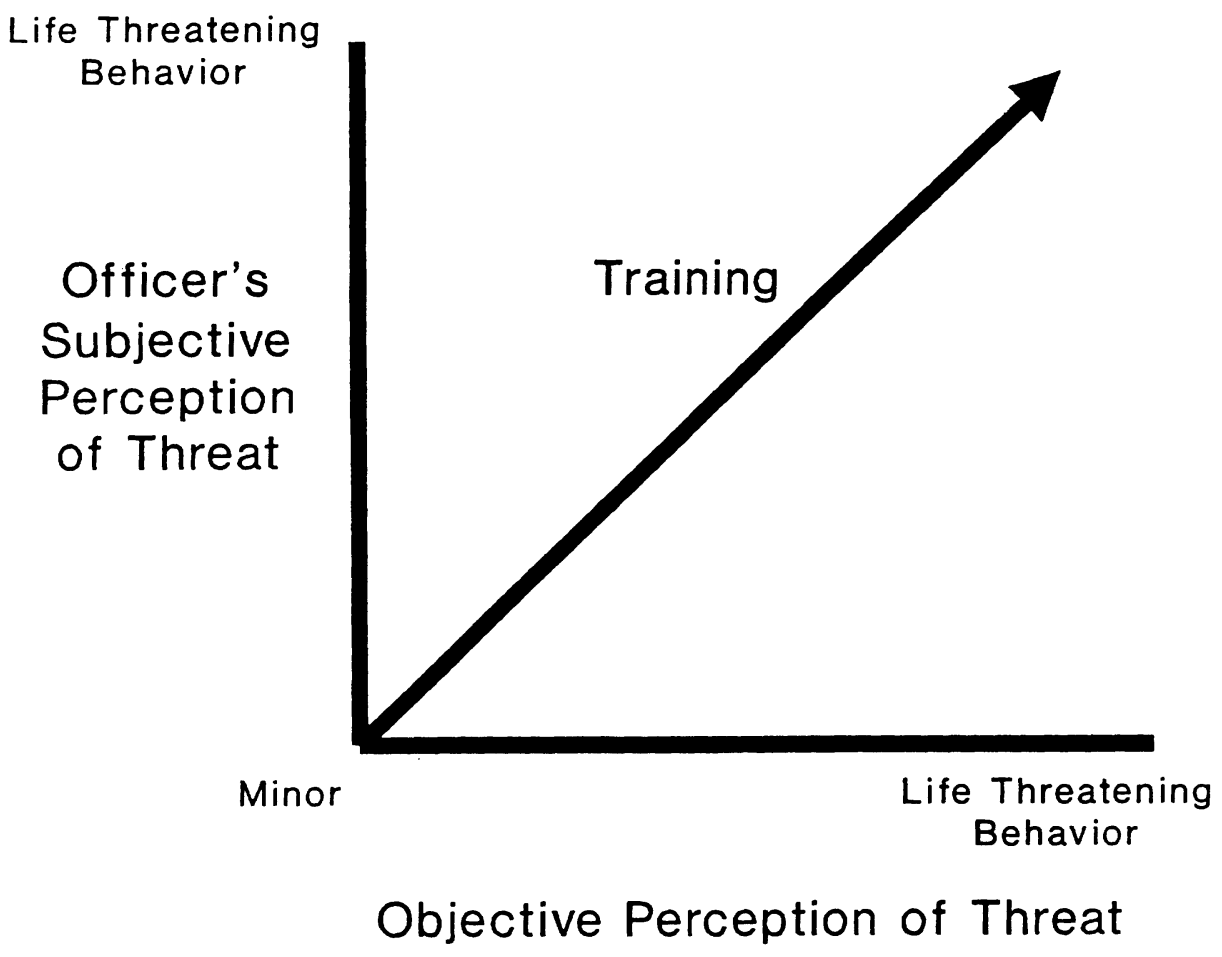

for back-up, and use a defensive maneuver or defensive weapon to remove the threat. Of course, if the perceived threat is an aimed firearm, regardless of its authenticity, an immediate and aggressive response may be necessary.

\section{Evaluating the Use of Force: A Concluding Comment}

This Article's formulation of excessive force relies upon a blend of motive, intent, and control. Unfortunately, it is easier to define excessive force than it is to identify or measure it. Similarly, it is difficult to determine its antecedents or causes. The research literature includes both objective tabulations and subjective speculation, but is based on hindsight and retrospective analysis. Despite that, these findings have provided many clues to the nature of police-citizen interactions. For example, one consistent observation is that police officers are likely to behave toward a citizen as the citizen has acted toward them:

More than anything else, policemen-like most of the rest of us-tend to respond in kind to the actions of the people they meet. If they can 
learn that their position imposes on them special responsibilities to respond as judiciously as possible, their use of force may become much less of a problem. Also, like most of the rest of us, the police appear to be concerned with maintaining their image in the eyes of their colleagues and the public. If they can learn to submerge short-term considerations of face in long-term considerations of professional prestige, they may find their use of force less controversial and their professional status on the rise. ${ }^{69}$

The immediate reaction of a police officer to a citizen with an "attitude" continues to be a visceral response rather than a calculated and ethically conditioned one. ${ }^{70}$ An additional influence on the police response to citizens is the public image that is created. Most police officers are aware of the professional damage caused by incidents such as the beating of Rodney King. Police managers express concern that the collective perception of the public, those "reasonable persons," may be anything but reasonable. ${ }^{71}$ This concern is likely driven by the awareness of the "subjective objectivity" inherent in the non-police perspective, and is contrasted with the "situational objectivity" which police officers formulate in their encounters with citizens.

Unfortunately, precious little operational guidance exists for the police administrator, training officer, or pro-active risk manager. Regardless of these shortcomings, both citizens and well-trained, objective police officers are likely to view aggravated police behavior similarly. The less extreme the behavior, the more disagreement is likely to surface among the observers or evaluators. An objective definition of excessive force continues to remain unreachable.

Some benchmark for police use of force must be created. The "reasonable person" is an unwieldy prospect for pro-active guidance for officer behavior and has a collective experience similar to the Minotaur looking for a way out of the Labyrinth. The categories and variables provided above are not designed to be a complete or exhaustive inventory. Rather, they represent the beginning of a dialogue among researchers, attorneys, and police officers. Officer training and agency atmosphere may explain the level of officers' use of force. However, it is a totality of situational circumstances and ethical acceptability which must be evaluated to determine if force used by a police officer is reasonable.

69 Friedrich, supra note 6 , at 97.

70 WALKER, supra note 63, at 331; KAPPELER ET AL., supra note 15, at 106.

71 Louis A. Radelet \& David L. Carter, The Police and the Community 203-05 (5th ed. 1994). 